\section{Poliomyelitis (Heine-Medin disease)}

$\mathrm{T}$ he recent death of FC Robbins ${ }^{1}$, Nobel laureate and pioneer worker who cultivated the poliomyelitis virus, prompts this note. Poliomyelitis pre-dates recorded history. ${ }^{2}$ Biblical descriptions of the lame and crippled lack sufficient detail for diagnosis. However, a funereal stele of the priest Ruma from the 19th Egyptian dynasty shows shortening and marked wasting of his right leg; he walks on his toes and uses a stick ${ }^{3}$; this has been attributed to poliomyelitis. ${ }^{4}$ Frequent 18th century epidemics allowed a British doctor, Michael Underwood, to describe poliomyelitis as an entity in 1789, referring to a "debility of the lower extremities in children" John Badham described an acute paralysis suggestive of poliomyelitis in four children in $1835 .^{6}$

Little more was written until Jacob von Heine published a 78 page monograph in 1840 , which recognised poliomyelitis as a disease entity (Heine also portrayed congenital spastic diplegia, later elaborated by Little in 1841). He separated the disease from other forms of paralysis and termed it infantile spinal paralysis. ${ }^{7}$ He described the residual deformities, and suspected a cord lesion. Heine was a German orthopaedist, born 16 April 1800 at Lauterbach. His family had a long tradition of bonesetting. Two years after graduation at Würzburg in 1827 and postgraduate work, he left Würzburg; the government elected him to organise an orthopaedic clinic in Cannstatt, which attracted patients from all over Europe. He died on 12 November 1879.

However, the limited prevailing medical knowledge prevented an understanding of the infectious nature of poliomyelitis. For example, a major epidemic in Vermont during 1894 was attributed to "overheating, chilling, trauma, fatigue, and illnesses such as typhoid, whooping cough, and pneumonia".

The pathology too was unknown until Duchenne in 1855, then Charcot and Joffroy, first located the atrophy in the anterior horns of the spinal grey matter. ${ }^{8}$ They ascribed it to

"an irritation that suddenly seizes a large number of cells

And, Erb reflected this when he coined the term "acute anterior poliomyelitis" in 1875. Usually named sporadic infantile paralysis, the Swedish Oskar Medin in 1890 reported its occurrence in epidemic form. Hence arose the eponym Heine-Medin disease.

\section{Prevention}

When in 1910 Levaditi and Landsteiner mixed live poliomyelitis virus with convalescent monkey serum, it failed to produce paralysis when injected into healthy monkeys; but this promising method proved ineffective in acute human poliomyelitis. Franklin Delano Roosevelt was stricken by poliomyelitis in 1921. A powerful politician, he was afflicted at a time when disability was a stigma. Roosevelt initially concealed his disability but The Atlanta Journal published an article, "Franklin D. Roosevelt Will Swim to Health", describing the therapeutic effect of the waters in Warm Springs, where in 1927 he established a therapeutic haven. Roosevelt's illness encouraged the medical battle against poliomyelitis.

\section{Poliomyelitis virus and immunisation}

The first decade of the 20th century saw substantial advances. Otto Wickman (1905) first recognised that poliomyelitis was infectious. Landsteiner and Popper proved the disease was transmissible to monkeys in 1909. One year later Flexner and Lewis showed poliomyelitis antibodies in convalescent monkey serum, and Netter with Levaditi showed antibodies in man. In Boston, John Franklin Enders, Frederick Chapman Robbins, and his classmate Thomas H Weller in 1949 cultured the Lansing strain of poliomyelitis virus in embryonic tissue culture, for which they received the 1954 Nobel Prize. Their methods paved the way for the culture of other viruses, for example measles, and the coronavirus that causes SARS. The virus enters through the mouth and nose, multiplies in the throat and intestinal tract, and spreads through the blood and lymphatic system. Incubation is from 5 to 35 days. Because epidemics continued and isolation and quarantine proved largely ineffective, the attempts to develop a poliomyelitis vaccine were to prove vital preventive measures. In 1955 Jonas Salk $^{9}$ developed the inactivated poliomyelitis virus vaccine, thus widespread immunisation began. This was followed in 1960 by a live, attenuated oral vaccine developed by Albert Sabin. ${ }^{10}$ The result was impressive. Wild poliomyelitis virus 2 was last detected in West Bihar, India, in 1999 and has not been found since. Worldwide, WHO reports confirmed poliomyelitis cases dropped from 7141 in 1999 to 2824 in $2000 .^{11}$

J M S Pearce J M S Pearce, 304 Beverley Road, Anlaby, East Yorks HU10 7BG, UK; jmspearce@freenet.co.uk

\section{References}

1 Obituary, FC Robbins. The Independent Friday 8 August 2003:18.

2 Sass EJ, ed. Polio's legacy: an oral history. Lantham, Maryland University Press of Amerand, 1996.

3 McHenry Lawrence C. In: Garrison's history of neurology. Springfield, Illinois: Charles C Thomas, 1969:4-5.

4 Paul JR. A history of poliomyelitis. New haven: Yale University Press, 1971.

5 Underwood M. Debility of the lower extremities. In: Treatise on the diseases of children. London: J Mathews, 1789;2:53-7. [Cited in: Norman JM, ed. Garrison and Morton's Medical Bibliography. 5th edn. Aldershot: Scolar Press, 1991;no 4662, p721.]

6 Badham J. Paralysis in childhood. Four remarkable cases of suddenly induced paralysis in the extremities without any apparent cerebral or cerebrospinal lesion. London Med Gaz 1835;17:215-8.

7 Heine J. Beobachtungen uber lahmungustande der untern extremitaten und deren behandlung. Stuttgart: FH Kohler, 1840.

8 Charcot JM. Joffroy A. 5th sér. Une observation de paralysie infantile $s^{\prime}$ accompagnant d'une alteration des cornes anterieures de la substance grise de la moelle. C R Soc Biol (Paris) 1870;1:312-5.

9 Salk JE. Studies in human subjects on active immunization against poliomyelitis. 1. A preliminary report. J Am Med Assoc 1953;151:1081-98.

10 Sabin AB. Characteristics and genetic potentialities of experimentally produced and naturally occurring variants of poliomyelitis virus. Ann N Y Acad Sci 1955;61:924-38.

11 WHO. Global eradication of poliomyelitis. Reports of the Fourth Meeting of the Global Technical Consultative Group for Poliomyelitis Eradication, Geneva, 1-2 June 1999. Geneva: WHO, 1999. 